DOI: $10.19195 / 2300-7729.37 .5$

\author{
JAGODA MAtgorZATA NOWAK \\ ORCID: 0000-0001-6451-536X \\ Biblioteka Jagiellońska
}

\title{
Praca bibliotekarza z perspektywy półwiecza na przykładzie Sekcji Informacji Naukowej Biblioteki Jagiellońskiej
}

\section{Wstęp}

Na przestrzeni dziejów biblioteki podlegały nieustannym zmianom stanowiącym wypadkową zasad, jakimi rządziły się poszczególne epoki, kręgi kulturowe oraz społeczeństwa. Przez stulecia były one jednocześnie wytworem i świadectwem swoich czasów, zależnym od zmian czynników mających wpływ na ich charakter i realizowane funkcje ${ }^{1}$. Zmieniające się okoliczności społeczne, kulturowe, a nawet historyczne wpłynęły na to, że biblioteki zaczęły być postrzegane nie tylko jako skarbnice, świątynie czy laboratoria ${ }^{2}$ mające wyłącznie ukryć książkę i umożliwić jej odnalezienie ${ }^{3}$. Takie założenia redukują działalność tych instytucji do ochrony książek, zapominając o pracach związanych z upowszechnianiem i promowaniem nie tylko samego księgozbioru, ale także kultury i wiedzy ${ }^{4}$. Postronny obserwator mógłby odnieść wrażenie, że biblioteki trwają w swojej niezmienionej formie od wieków, jednak z perspektywy pracownika zmieniły się, zaktualizowały formę i założenia. Można przyjąć, że zmiany, jakie zaszły w usługach i procesach bibliotecznych, są wynikiem wpływu czynników historyczno-politycznych i technologicznych. Te pierwsze odpowiadają za stabilne warunki polityczne i gospodarcze sprzyjające rozwojowi bibliotekarstwa, drugie zaś wprowadziły znaczące przeobrażenia w sposobie życia, komunikacji i pracy ludzi, pośrednio wymuszając zmiany również w funkcjonowaniu bibliotek.

1 J. Grycz, Historia bibliotek w zarysie, Warszawa 1950, s. 13-14.

2 A. Tokarska, Biblioteka w przestrzeni informacyjnej, [w:] Bibliotekarstwo, red. A. Tokarska, Warszawa 2013, s. 728.

${ }^{3}$ U. Eco, O bibliotece, Warszawa 2007.

4 J. Nowak, Biblioteka = przyjazne miejsce, „Biuletyn EBIB” 2016, nr 5, s. 1, http://open. ebib.pl/ojs/index.php/ebib/article/view/448 [dostęp: 6.01.2019]. 


\section{Edukacja kadr bibliotecznych}

Przemiany w edukacji bibliotekarzy na poziomie wyższym można zaprezentować na przykładzie studiów bibliotekoznawczych Uniwersytetu Jagiellońskiego. Tradycje uniwersyteckich wykładów z bibliografii sięgają tu roku 1811. Zajęcia w tym obszarze prowadzili tu między innymi Jerzy Samuel Bandtkie, Józef Muczkowski czy Aleksander Birkenmajer. W latach 1949-1951 dla studentów studiów filologicznych, filozoficznych i historycznych utworzono specjalizację bibliotekarską, a w latach 1969-1975 zaczęło funkcjonować Międzywydziałowe Studium Bibliotekoznawstwa, którego program stanowił podstawę merytoryczną utworzonego w 1973 roku na Wydziale Filologicznym Zakładu Bibliotekoznawstwa i Informacji Naukowej. Na początku lat dziewięćdziesiątych XX wieku Zakład przemianowano na Katedrę, a w 1996 roku na Instytut Bibliotekoznawstwa i Informacji Naukowej (obecnie podlegający Wydziałowi Zarządzania i Komunikacji Społecznej). Niemalże od początku organizatorzy studiów oferowali swoim studentom zarówno studia stacjonarne, jak i zaoczne, później wzbogacając ofertę o studia podyplomowe, a także krótkie kursy dokształcające ${ }^{5}$. Ważnym momentem dla Instytutu był rok 2007, w którym uzyskał on uprawnienia do nadawania stopnia naukowego doktora nauk humanistycznych w dyscyplinie bibliologia i informatologia.

$\mathrm{Z}$ biegiem lat zmieniła się nie tylko nazwa Instytutu i jego miejsce w strukturze uniwersyteckiej, ale także lokalizacja. Pierwszą siedzibą Zakładu był stary gmach Biblioteki Jagiellońskiej. Następnie przeniesiono Katedrę na ulicę Gołębią, gdzie przytulne pomieszczenia, bliskość starego miasta oraz majestatyczne zabudowania centralnej infrastruktury Uniwersytetu przywodziły na myśl dawny klimat życia krakowskiego żaka. Mniej więcej od roku 2003 siedziba Instytutu została przeniesiona na Kampus 600-lecia Odnowienia Uniwersytetu Jagiellońskiego, jednak dopiero później otrzymał on własne pomieszczenia w nowo otwartym budynku Wydziału Zarządzania i Komunikacji Społecznej. Wówczas studenci bibliotekoznawstwa wkroczyli w XXI wiek: klimatyzowane pomieszczenia, nowoczesne urządzenia, w pełni wyposażone sale komputerowe z dostępem nie tylko do Internetu, ale także do baz danych i nowoczesnego oprogramowania stanowią doskonałe zaplecze do kształcenia przyszłych bibliotekarzy.

Wraz z przemianami społecznymi ewoluował również sam kierunek i jego podstawa programowa. Początkowo, od 1974 roku, kierunek nazywał się: bibliotekoznawstwo i informacja naukowa. Aby zostać jego studentem, konieczne było zdanie egzaminu wstępnego. Program umożliwiał studiowanie historii książki, drukarstwa, księgarstwa, bibliotek, bibliotekarstwa oraz bibliografii. Oferowano

5 M. Kocójowa, Raport Katedry Bibliotekoznawstwa i Informacji Naukowej Uniwersytetu Jagiellońskiego w Krakowie, Kraków 1995, s. 71, http://www.inib.uj.edu.pl/podstawowe-informacje [dostęp: 6.01.2019]. 
również wykłady z bibliotekoznawstwa i bibliotekarstwa, zagadnień czytelnictwa, dokumentacji i informacji naukowej oraz polityki kulturalnej $\mathrm{PRL}^{6}$. Na studiach odbywały się także między innymi zajęcia z maszynopisania ${ }^{7}$. Taka podstawa programowa utrzymywała się aż do lat dziewięćdziesiątych XX wieku, kiedy to zmiany w obszarze technologii wymusiły na organizatorach studiów szersze otwarcie się na informację naukową. Wówczas do siatki zajęć wpisano wykłady i ćwiczenia z baz danych, języków programowania, użytkowania oprogramowania bibliotecznego i systemów informacyjnych oraz komputeryzacji, systemów eksperckich, wyszukiwania w elektronicznych źródłach informacji i wykorzystywania mikrokomputera do prac wydawniczych ${ }^{8}$. Wpływy te ostatecznie doprowadziły do zmiany nazwy kierunku na informację naukową i bibliotekoznawstwo (od 2003 roku). Odwrócenie kolejności wyrazów jednoznacznie wskazywało, na jakie zagadnienia władze Instytutu chciały kłaść nacisk. Był to jednak czas przejściowy, w którym równowaga między ilością treści z bibliotekarstwa $\mathrm{i}$ informacji naukowej była zachowywana. Studiując w tym okresie (rok akademicki 2008/2009), byłam przygotowywana do pracy w bibliotece poprzez nabywanie nowych kompetencji specjalisty informacji, który oprócz wiedzy o tradycyjnych źródłach powinien być wyposażony w umiejętności poruszania się po zasobach wirtualnych. Wśród zajęć znajdowały się między innymi tzw. formaty, uczące katalogowania różnego typu dokumentów, źródła informacji, przygotowujące do pracy z różnymi rodzajami źródeł, czy podstawy bibliotekoznawstwa. Wykładowcy przybliżali nam historię bibliotek, druku i księgarstwa, kwestie dotyczące pracy z czytelnikiem czy ruchu wydawniczo-księgarskiego. Z kolei ukłonem w kierunku informacji naukowej były zajęcia $z$ Internetu jako środowiska informacyjnego, przysposabiające do wykonywania kwerend głównie w oparciu o bazy danych i Internet, systemy i języki informacyjno-wyszukiwawcze czy projektowanie i ocena systemów informacji. Dodatkowo poszerzaliśmy swoje horyzonty w zakresie: tworzenia stron WWW, prowadzenia własnej działalności gospodarczej, poznawania prawa własności intelektualnej czy projektowania baz danych ${ }^{9}$. Następna zmiana nazwy kierunku, na zarządzanie informacją, nastąpiła w roku akademickim 2014/2015. Obecnie widać mocny trend w kierunku kształcenia nie tyle przyszłych kadr bibliotecznych, ile infobrokerów (choć jedno nie wyklucza drugiego). Przeglądając Plan studiów I stopnia na kierunku zarządzanie informa-

${ }^{6}$ Międzywydziałowe Studium Bibliotekarstwa UJ, [w:] Spis wykładów na rok 1971/72 Wydziat Filozoficzno-Historyczny, Kraków 1971, z. 2, s. 72-74.

7 Indeks Barbary Bułat wystawiony przez Uniwersytet Jagielloński w dniu 1 października 1981 roku.

${ }^{8}$ M. Kocójowa, Librarianship and Information Science Education and Library Staff Training in Poland, [w:] Modern Libraries and Librarianship in Poland, red. M. Kocójowa, A. Altenberger, Kraków 1995, s. 19.

${ }^{9}$ Indeks Jagody Nowak wystawiony przez Uniwersytet Jagielloński w dniu 1 października 1981 roku. 
cją rozpoczynających się w roku 17/18, można zauważyć, że wiele przedmiotów dotyczy głównie pozyskiwania, przetwarzania i zarządzania informacją. Rozpatrywane są kwestie zachowań informacyjnych, zarządzania danymi i tożsamościami w środowisku cyfrowym oraz wizualizacji i estetyki informacji. Wciąż występuje czytelnictwo, podstawy teorii i metodologii bibliologii czy podstawy bibliotekarstwa, nie wydaje się jednak, by stanowiły one trzon programu nauczania i są oferowane studentom dopiero w późniejszych semestrach nauki ${ }^{10}$.

Na przestrzeni lat zmianom uległ również charakter i wymiar praktyki zawodowej. Początkowo były one płatne i odbywały się po każdym roku studiów, przez pierwsze trzy lata w wymiarze jednego miesiąca. Podczas pierwszej praktyki studenci zapoznawali się z opracowaniem formalnym książki (studenci uczyli się wówczas między innymi druczkiem bibliotekarskim wypisywać karty katalogowe). Druga praktyka miała nauczyć studentów opracowania rzeczowego, a trzecia przysposobić ich do działalności informacyjnej w bibliotece ${ }^{11}$. W czasie studiów konieczne było odbycie dwóch miesięcznych, bezpłatnych praktyk. Pierwsze praktyki odbywały się po pierwszym roku nauki i przysposabiały do opracowywania rzeczowego i formalnego rożnego typu dokumentów. $Z$ kolei druga praktyka, związana z informacją naukową, miała służyć nabraniu biegłości w świecie informacji i bezpośredniej obsłudze czytelników. Analizując aktualne plany nauczania na kierunku zarządzanie informacją, można wywnioskować, że student odbywa jedną miesięczną praktykę, która nie musi mieć miejsca w bibliotece. Może ona zostać zorganizowana w przedsiębiorstwie, instytucji samorządowej i państwowej, ośrodkach informacji, firmach infobrokerskich i innych ośrodkach, w których gromadzi się, przetwarza i udostępnia informacje ${ }^{12}$.

Podsumowując, na przykładzie Uniwersytetu Jagiellońskiego widać, że przemiany w sposobie edukowania bibliotekarzy następowały dość systematycznie. Niektóre z nich były mniej, inne bardziej radykalne, jednak przeważnie miały na celu to, by iść z duchem czasu. Zmieniające się warunki społeczne, polityczne czy nawet geograficzne rodziły konieczność dostosowania programów nauczania tak, by absolwent zyskał kompleksowy pakiet umiejętności bibliotekarskich i informacyjnych, potrzebny we współczesnym świecie. Starano się go przygotować nie tylko do pracy w kraju, ale także w szeroko pojmowanym międzynarodowym środowisku, czemu już od lat dziewięćdziesiątych XX wieku służyły liczne wymiany studentów, obecnie głównie związane z programem ERASMUS.

10 Plan studiów I stopnia na kierunku zarządzanie informacja - studia rozpoczynajace się w roku 17/18, http://www.inib.uj.edu.pl/studia-1-stopnia [dostęp: 6.01.2019].

11 Barbara Bułat, urodzona 18 lipca 1962 roku, wywiad przeprowadzony w Krakowie dnia 17 października 2017 roku.

12 Plan studiów I stopnia na kierunku zarządzanie informacja - studia rozpoczynajace się w roku $17 / 18 \ldots$ 


\section{Bibliotekarz i jego stanowisko pracy}

Od wielu lat mogliśmy obserwować zachodzące w społeczeństwie transformacje kulturowe, które wymusiły na bibliotekarzach zmianę ich postaw wobec czytelników. Musieli oni przestać uważać czytelnika „za wroga, nieroba [...], za potencjalnego złodzieja"13 i zacząć zachowywać się jak życzliwy przewodnik po zawiłym świecie informacji. Wygląd bibliotekarza, zależny od kultury, systemu pracy oraz trendów w modzie, bazował na praktycznym i adekwatnym do wykonywanej pracy stroju. Powinien on być na tyle wygodny, aby nie ograniczał ruchów, oraz odpowiednio schludny, by godnie reprezentować bibliotekę. Nie można również zapominać o tym, że praca w bibliotece wiąże się z przebywaniem przy zakurzonych zbiorach, gdzie konieczne jest stosowanie odzieży ochronnej. W latach osiemdziesiątych ubiegłego wieku to zakład pracy zapewniał służbowy fartuch, obuwie, ręcznik, mydło, papier toaletowy oraz proszek do prania ${ }^{14}$. Niecodziennym obecnie elementem wyposażenia ówczesnego biurka była butelka na służbowe mleko ${ }^{15}$. Obecnie mydło jest dostępne w toaletach, pracodawca dostarcza rękawiczki, a pracownik sam troszczy się o czystość swojej odzieży.

Stanowisko pracy bibliotekarza również uległo drobnemu „tuningowi”. W Sekcji Informacji Naukowej BJ (obecna nazwa) mniej więcej od roku 1951 na jednym z biurek znajdowała się maszyna do pisania (wówczas marki Underwood) ${ }^{16}$, a od 1954 roku także telefon stacjonarny, zainstalowany w związku z uruchomieniem centrali telefonicznej ${ }^{17}$. Dwa lata później wyposażenie Sekcji wzbogaciło się dodatkowo o: aparaty do zdjęć mikrofilmowych firmy Zeiss (jeden do mikrofilmowania rękopisów i druków, drugi do czasopism) oraz cztery lektory (Zeiss) do odczytywania mikrofilmów ${ }^{18}$. Na biurku bibliotekarza $\mathrm{z}$ lat osiemdziesiątych XX wieku koniecznie musiało znajdować się tzw. korytko, a w nim: ołówki, temperówka oraz zapasowe taśmy do maszyny do pisania. Dodatkowo bibliotekarz wykorzystywał pieczątki, co oznacza, że na jego biurku leżała także poduszka i tusz. We wrześniu 1991 roku w pracowni podłączono komputer IBM PC/ AT firmy River z kolorowym monitorem oraz drukarką. Rok później do zestawu dołączono czytnik CD-ROM umożliwiający korzystanie z pierwszej bazy danych Humanities Index. W tym samym roku podejmowano pierwsze próby obsługi poczty elektronicznej oraz wdrażano się do używania elektronicznej maszyny do

13 U. Eco, op. cit., s. 14.

14 „Ariadna w labiryncie informacji: 60-lecie Oddziału Informacji Naukowej i Katalogów Biblioteki Jagiellońskiej" (11 stycznia 2011), materiały robocze zebrane w celu opracowania wystawy.

15 Ibidem.

16 Okólnik nr 7 z 22 stycznia 1951 dotyczący przydziału maszyn do pisania.

17 Okólnik nr 27 z 28 lipca 1954 B-1a/27/3/54 dotyczący uruchomienia centrali telefonicznej.

18 Planowanie budżetowe na rok 1956 w Oddziale Informacji Bibliograficznej z dnia 30 czerwca 1955 roku. 
pisania Erica (produkcji NRD). Dopiero w 1995 roku na komputerach zainstalowano system operacyjny Windows umożliwiający przeglądanie stron $\mathrm{WWW}^{19}$.

Niewiele zmieniło się w wyglądzie biurka, a to, co znajduje się na nim obecnie, jest zależne od wykonywanych zadań. Główną różnicą na pewno jest to, że każdemu pracownikowi przydzielono osobny komputer stacjonarny, a system wirtualnych dysków pozwala na stały dostęp do materiałów służbowych. Ze względu na długotrwałą pracę przy „,pecetach”, na biurku pojawiła się żelowa podkładka pod mysz odciążająca nadgarstek, wygodny fotel biurowy ze specjalną matą chroniącą odcinek lędźwiowy kręgosłupa oraz środki chemiczne pozwalające zachować sprzęt komputerowy w czystości. Dodatkowo za pośrednictwem komputerów pracownicy mają dostęp do Internetu, systemu bibliotecznego Virtua, subskrybowanych baz danych, uniwersyteckiej poczty elektronicznej oraz do tzw. Sparka, czyli służbowego komunikatora. Każdy z nas trzyma na biurku także jakiś zestaw przyborów do pisania (czasem wciąż w korytkach), pojemniki biurowe do przechowywania dokumentów oraz kontenerki na rzeczy osobiste. Dodatkowo, w zależności od obowiązków, na biurku bibliotekarza wciąż mogą pojawić się tradycyjne rewersy, karty katalogowe, maszyna do pisania, pieczątki czy telefon. Część pracowników korzysta z czytników kodów kreskowych, skanera i aparatu cyfrowego. Na stanie pracowni wciąż znajdują się wózki biblioteczne, jednak po wprowadzeniu systemu TeleLift są one wykorzystywane jedynie do realizacji wewnętrznych potrzeb Sekcji.

\section{Warsztat pracy i zakres obowiązków bibliotekarza}

Większą różnorodność zyskał również warsztat pracy oraz zakres obowiązków bibliotekarza. Przed komputeryzacją zmiany następowały raczej powoli i miały na celu bardziej udoskonalenie działań niż ich całkowitą transformację. Jednak wraz z instalacją komputerów i Internetu pojawiły się nowe możliwości, usprawniające wykonywanie obowiązków. Obecnie niemal każdy aspekt pracy bibliotekarza w jakiś sposób powiązany jest z pracą przy komputerze.

Wśród głównych zadań bibliotekarzy zatrudnionych w Sekcji Informacji Naukowej było i nadal jest realizowanie kwerend, udzielanie informacji telefonicznych oraz pełnienie dyżuru informacyjnego w Czytelni ${ }^{20}$. Rzeczą, która nie zmieniła się od lat, jest to, że nowi pracownicy nabywają prawo do samodzielnego udzielania informacji dopiero po przejściu wewnętrznego szkolenia i okresu karencji, kiedy to wyniki ich pracy są kontrolowane przez bardziej doświadczonych kolegów. Kontrola działań nowego adepta informacji jest istotna, gdyż do realizacji

19 Sprawozdania Oddziału Informacji Naukowej za lata 1991-2010.

20 B. Bułat, Zmarli bibliotekarze Uniwersytetu Jagiellońskiego: Irena Czerni, „Biuletyn Biblioteki Jagiellońskiej” 65, 2015, s. 265-275. 
kwerend $\mathrm{i}$ informowania konieczna jest dobra orientacja w księgozbiorze, posiadanie ogólnego rozeznania w bibliografiach oraz innych źródłach informacji, a także posiadanie umiejętności efektywnego przeszukiwania katalogów bibliotecznych, zwłaszcza w momencie kiedy w bibliotece jednocześnie funkcjonuje kilka różnych ich typów. Przykładowo, w Bibliotece Jagiellońskiej od lat trzydziestych XX wieku do okresu po drugiej wojnie światowej występował między innymi katalog klamrowy stanowiący wyciąg najważniejszych informacji z nieudostępnianego wówczas czytelnikom tzw. katalogu starego ${ }^{21}$ oraz tzw. kartoteka obrzeżnie perforowana rejestrująca zawartość szesnastu fachowych czasopism bibliotekarskich i naukoznawczych od lat sześćdziesiątych XX wieku.

Początkowo kwerendy do Biblioteki Jagiellońskiej trafiały głównie listownie i w okresie przedkomputerowym były realizowane w oparciu o księgozbiór z wykorzystaniem dość prostych narzędzi, do których zaliczały się długopis, kartka, maszyna do pisania i czasem kserograf ${ }^{22}$. Wraz z pojawieniem się w bibliotece pierwszego komputera nastał okres zmian. Początkowo komputer usprawnił jedynie proces odpowiadania na listy, pomagając pracownikom w ich szybszej redakcji i powielaniu. Następnie zakup czytników CD-ROM zwiększył pulę źródeł informacji o bazy danych występujące na płytach $\mathrm{CD}$, a od momentu upowszechnienia się ogólnoświatowej sieci WWW dostępnych w postaci subskrypcji. Sieć WWW umożliwiła także wyszukiwanie informacji w ogólnoświatowych zasobach, często zagregowanych w darmowe lub płatne bazy, informatory i serwisy. Dużym ułatwieniem w opracowywaniu kwerend stały się również ogólnodostępne katalogi biblioteczne, biblioteki cyfrowe oraz wszelkiego typu elektroniczne archiwa i kartoteki, dzięki którym możemy zdalnie przeszukiwać zasoby polskich i zagranicznych instytucji, a także kontaktować się z ich pracownikami w poszukiwaniu wsparcia merytorycznego. Obecnie cały proces wykonania kwerendy od momentu jej otrzymania, poprzez opracowanie, po przesłanie odpowiedzi opiera się na wykorzystaniu komputera, a komunikacja listowna jest coraz rzadsza. W pewnym sensie sami warunkujemy takie działania, udostępniając naszym czytelnikom na głównej stronie biblioteki nie tylko formularz kontaktowy Zapytaj Bibliotekarza, ale także liczne adresy e-mail.

Kolejnym zadaniem służbowym bibliotekarza, które uległo transformacji, jest szeroko pojmowana dydaktyka biblioteczna. Działalność tego typu w Sekcji Informacji Naukowej organizowano niemal od początku jej istnienia, jednak spotkania odbywały się raczej sporadycznie i głównie na specjalne zamówienie pracowników naukowych. Zajęcia miały na celu prezentację drukowanych bibliografii i innych źródeł informacji z danej dziedziny. Pojawiające się na początku lat dziewięćdziesiątych XX wieku pierwsze zasoby elektroniczne wymusiły

${ }^{21}$ L. Stachnik, Zarys dziejów katalogu alfabetycznego Biblioteki Jagiellońskiej, „Biuletyn Biblioteki Jagiellońskiej” 25, 1975, s. 104; Anna Grzęda, urodzona 16 września 1962 roku, wywiad przeprowadzony w Krakowie dnia 6 listopada 2017 roku.

22 B. Bułat, op. cit., s. 265-275. 
na bibliotekarzach uwzględnienie ich w programach szkoleń i pokazów. Jednak problemy lokalowe oraz brak wystarczającej liczby stanowisk komputerowych sprawiały, że prowadzenie tego typu zajęć było problematyczne ${ }^{23}$. Dopiero oddany do użytku w 2000 roku nowy gmach Biblioteki Jagiellońskiej stworzył lepsze warunki do pracy dydaktycznej, oferując prowadzącym dostęp do dużej sali konferencyjnej, a także wygospodarowanej salki seminaryjnej ze stanowiskami komputerowymi. W nowym otoczeniu zamawiane zajęcia były organizowane aż do 2005 roku, kiedy to postanowiono wdrożyć szkolenia o nazwie Ars Quaerendi (AQ), mające odbywać się zgodnie z ustalonym uprzednio harmonogramem. Od tego momentu spotkania przybliżały słuchaczom zasady poruszania się po elektronicznych bibliografiach i innych źródłach informacji. Dodatkowo pracownicy Sekcji zaoferowali również możliwość zorganizowania szkoleń AQ na zamówienie. Wówczas takie spotkania są przygotowywane specjalnie pod konkretny temat, zagadnienie lub profil słuchaczy. Jednak nie oznacza to, że obecnie Biblioteka Jagiellońska uczy jedynie zasad korzystania ze zbiorów elektronicznych. Wraz z kustosz Barbarą Bułat próbujemy wskrzesić lekcje biblioteczne prezentujące tradycyjne, to jest drukowane źródła informacji, pokazując jednocześnie ich powiązania ze źródłami dostępnymi zdalnie. Wykorzystując tryb gry terenowej, zlokalizowanej w Czytelni Informacji Naukowej, staramy się uzmysłowić czytelnikom, że w świecie informacji nie można wybrać tylko wersji drukowanej albo elektronicznej źródeł, gdyż pełnię wiedzy możemy uzyskać tylko wtedy, gdy oba te zasoby wykorzystamy równocześnie. Dodatkowo scenariusze gier ukierunkowane są również na to, aby podczas rozgrywki ,przemycać” czytelnikowi podstawowe informacje dotyczące zasad korzystania z biblioteki. Jednak nasza działalność dydaktyczna, oprócz cyklicznych szkoleń, prowadzona jest niemal codziennie, podczas pełnienia dyżuru informacyjnego często bowiem szkolimy czytelników w sposobach korzystania z baz danych, katalogów bibliotecznych, a nawet zasobów ogólnodostępnych w Internecie. Coraz częściej pracownicy Sekcji Informacji Naukowej prowadzą lekcje biblioteczne, instruktaże dla czytelników lub szkolenia z obsługi nowych aplikacji (np. Mendeley). Wszystkim czytelnikom oferujemy także usługę Bibliotekarz dla Ciebie, dzięki której mogą oni umówić się z bibliotekarzem na konkretny termin, aby był on ich osobistym mentorem w świecie informacji, a także przewodnikiem po budynku biblioteki.

Stałym elementem obowiązków bibliotekarskich, który także ewoluował, jest działalność wydawnicza i informacyjna. Na początku pracownicy Sekcji odpowiadali za redagowanie drukowanych ulotek informujących o Bibliotece, instrukcji korzystania ze zbiorów bibliotecznych, poradników, różnego rodzaju materiałów informacyjno-instruktażowych dotyczących posługiwania się informacją,

${ }^{23}$ B. Bułat, Wspótpraca Biblioteki Jagiellońskiej ze środowiskiem naukowym i studentami Uniwersytetu Jagiellońskiego w Krakowie, [w:] Biblioteki w procesie dydaktycznym i badaniach naukowych: III Konferencja Biblioteki Politechniki Łódzkiej, Łódź, 25-27 czerwca 2008 r.: materiały konferencyjne, Łódź 2008, s. 343-344. 
tworzenia bibliografii, pisania prac naukowych. Wraz z rozwojem środowiska wirtualnego zaczęli oni odpowiadać za opracowanie zamieszczanych na stronie WWW Biblioteki poradników i instrukcji dotyczących korzystania z czytelń i katalogów oraz sposobów zamawiania książek ${ }^{24}$. Przygotowywali także proste zestawienia bibliograficzne, głównie na własny użytek, jednak od lat siedemdziesiątych ubiegłego wieku usystematyzowali prace w tym obszarze, w wyniku czego między innymi stworzyli: Bibliografię publikacji o Uniwersytecie Jagiellońskim czy Bibliografię przybytków zagranicznych Biblioteki Jagiellońskiej i bibliotek instytutowych. Ponadto opracowali różnego rodzaju katalogi tematyczne, których jedynym zachowanym do dziś przedstawicielem jest kartoteka biobibliograficzna. Początkowo była ona opracowywana w postaci standardowego katalogu, następnie przekształcono ją w prostą bazę danych, która w zmienionej i ulepszonej formie funkcjonuje do dzisiaj pod nazwą Baza Biogramów Biblioteki Jagiellońskiej. Obecnie dzięki szybszemu dostępowi do informacji, głównie za sprawą Internetu i komputera, bibliotekarze przygotowują różne bibliografie, które często stanowią odpowiedź na liczne, kierowane do nich zapytania. W ten sposób w ostatnim czasie powstała na przykład Bibliografia poradników savoir vivre, a w przygotowaniu jest Bibliografia publikacji o Nekropoliach i Bibliografia dotycząca życia i twórczości Brata Alberta.

Dzięki swojej wiedzy w zakresie źródeł informacji bibliotekarze mieli duży wpływ na kształt pierwotnej wersji strony WWW Biblioteki Jagiellońskiej, pracując nad jej wyglądem, zawartością i aktualnością. Wraz ze zmianą charakteru strony i przekształceniem jej w ogólnoinformacyjny serwis zintegrowany z portalem UJ zmieniły się wpływy pracowników Sekcji na zamieszczane w serwisie treści. Redagują oni jednak znajdujące się tam spisy linków do ogólnodostępnych baz danych polskich i zagranicznych oraz spis Bibliografie Polskie dający dostęp do wykazu polskich bibliografii i informatorów. Pracownicy Sekcji Informacji Naukowej byli odpowiedzialni za pojawienie się w 2012 roku Biblioteki Jagiellońskiej w serwisie społecznościowym Facebook. Obecnie, mimo że oficjalny profil Biblioteki jest administrowany przez Sekcję Wydarzeń Kulturalnych, mają oni możliwość publikowania postów. Starają się informować czytelników o organizowanych w Czytelni ekspozycjach nowości, usługach (na przykład Bibliotekarz dla Ciebie i Zapytaj Bibliotekarza) oraz wydarzeniach mających miejsce w Czytelni. Ponadto każdy użytkownik Facebooka, który prześle zapytanie czy kwerendę tą drogą, może być pewien uzyskania informacji zwrotnej.

Ostatnią czynnością, w którą bibliotekarze chętnie się angażują, jest organizowanie wystaw. Nie tylko pomagamy w ich przygotowywaniu, ale także organizujemy samodzielne wystawy tematyczne i okolicznościowe. W Czytelni Infor-

${ }^{24}$ B. Baś, Wplyw nowych technologii na informację naukowa w Bibliotece Uniwersyteckiej na przykładzie Oddziatu Informacji Naukowej i Katalogów Biblioteki Jagiellońskiej, [w:] Biblioteka akademicka: infrastruktura - uczelnia - otoczenie: Gliwice, 24-25 października 2013 r., red. M. Odlanicka-Poczobutt, K. Zioło, Gliwice 2014, s. 58. 
macji Naukowej systematycznie opracowujemy ekspozycję nowości zarówno dla publikacji nowych w bibliotece, jak i w naszej czytelni. Innowacją w tej sferze jest przygotowywanie wirtualnych wystaw i umieszczanie ich w Jagiellońskiej Bibliotece Cyfrowej — przykładowo: Bolesław Leśmian (1877-1937) — magia stów, Święty Brat Albert (1845-1916) — setna rocznica śmierci czy Ewa Bąkowska, jaka znaliśmy, jakiej nie poznaliśmy.

Dodatkowo pracownicy Sekcji Informacji współpracowali z Jagiellońską Biblioteką Cyfrową w początkowej fazie prac nad Repozytorium Uniwersytetu Jagiellońskiego i wciąż zajmują się częścią zadań mających na celu opracowanie sylabusów (dostępnych w systemie USOS), współpracując z Działem Projektów ${ }^{25}$.

\section{Podsumowanie}

Transformacje społeczne, kulturowe, historyczne i technologiczne miały duży wpływ na to, jak zmienił się nie tylko sam bibliotekarz, ale także środowisko jego pracy i zakres jego obowiązków. Powyższe czynniki, a zwłaszcza nowe technologie wpłynęły na to, że z jednej strony dotychczasowe czynności biblioteczne przeobraziły się, a z drugiej pojawiło się wiele nowych. Wraz z rozwojem Internetu znacznie powiększył się zasób źródeł informacji, z których może skorzystać przeciętny bibliotekarz. Zniesione zostały bariery przestrzenne, gdyż za jednym kliknięciem myszy możemy przeszukiwać kolekcje należące do różnych instytucji, korzystać z elektronicznych wersji ich zbiorów, a nawet szybko skontaktować się z kimś pracującym po drugiej stronie globu. Czynniki te wymusiły również pewne zmiany w postawie samego bibliotekarza. Obecnie nie może on skupiać się jedynie na zabezpieczaniu zbiorów tradycyjnych. Musi stać się brokerem informacji potrafiącym nie tylko pozyskać dane i informacje, ale też umiejącym przetwarzać je, interpretować i w adekwatny do odbiorcy sposób przedstawiać wyniki swoich poszukiwań. Teraz bardziej niż kiedykolwiek bibliotekarze powinni uzbroić się w cierpliwość, wyrozumiałość i spore pokłady empatii, gdyż coraz częstsze obcowanie z homo tabletis $^{26}$ — człowiekiem tabletowym będzie testować ich profesjonalizm, wiedzę i umiejętności poruszania się w zasobach zarówno tradycyjnej, jak i elektronicznej wiedzy.

Pojawienie się Internetu nie tylko zmieniło bibliotekarzy, ale wpłynęło też na zachowania informacyjne czytelników. Od momentu upowszechnienia się nowych technologii liczba zapytań wysyłanych do biblioteki drogą e-mailową zaczęła rosnąć, a liczba otrzymywanych listów maleć. Obecnie czytelnicy piszą do biblioteki

25 Barbara Bułat, urodzona 18 lipca 1962 roku, wywiad przeprowadzony w Krakowie dnia 6 listopada 2017 roku.

${ }^{26}$ Homo tabletis - pojęcie zaczerpnięte z filmu Fundacji Dzieci Niczyje przygotowanego w ramach kampanii społecznej Mama, tata, tablet, https://www.youtube.com/watch?v=YmX20QCtBvw [dostęp: 6.01.2019]. 
nie tylko w sprawach poważnych i ambitnych, ale także błahych, lecz dla nich niemniej istotnych. Analizując statystyki Sekcji Informacji Naukowej za ostatnie sześć lat (2010-2016), można stwierdzić, że pomimo niewielkiego spadku liczby odwiedzin w Czytelni Informacji Naukowej liczba wykonanych przez pracowników kwerend i udzielonych informacji znacząco wzrosła. Czytelnicy oczekują od biblioteki stałego udoskonalania jakości oferowanych usług oraz prezentowania i przekazywania nierzadko obszernych informacji w przyjazny i łatwo przyswajalny sposób. Chcą, by zasoby biblioteczne były udostępniane zdalnie, a jeśli jest to niemożliwe, aby do minimum ograniczyć czas realizacji usługi.

Podsumowując, wydaje się, że w szeroko pojmowanym bibliotekarstwie najbardziej zmienił się system edukacji bibliotekarzy oraz czytelnicy i ich potrzeby informacyjne. Takie elementy, jak charakter pracy, obowiązki i warsztat pracy bibliotekarza, nie uległy całkowitemu przeobrażeniu i nie różnią się od stanu początkowego. Wydaje się, że wszystkie te elementy jedynie ewoluowały w coś bogatszego i lepiej funkcjonującego oraz że zmieniła się technologia procesu, ale nie proces sam w sobie.

\section{Bibliografia}

Baś M., Wpływ nowych technologii na informację naukową w Bibliotece Uniwersyteckiej na przykładzie Oddziału Informacji Naukowej i Katalogów Biblioteki Jagiellońskiej, [w:] Biblioteka akademicka: infrastruktura — uczelnia — otoczenie: Gliwice, 24-25 października 2013 r., red. M. Odlanicka-Poczobutt, K. Zioło, Gliwice 2014, s. 51-64.

Bułat B., Współpraca Biblioteki Jagiellońskiej ze środowiskiem naukowym i studentami Uniwersytetu Jagiellońskiego w Krakowie, [w:] Biblioteki w procesie dydaktycznym i badaniach naukowych: III Konferencja Biblioteki Politechniki Łódzkiej, Łódź, 25-27 czerwca 2008 r.: materiaty konferencyjne, Łódź 2008, s. 343-344.

Bułat B., Zmarli bibliotekarze Uniwersytetu Jagiellońskiego: Irena Czerni, „Biuletyn Biblioteki Jagiellońskiej" 65, 2015, s. 265-275.

Eco U., O bibliotece, Warszawa 2007.

Grycz J., Historia bibliotek w zarysie, Warszawa 1950.

Homo tabletis — film Fundacji Dzieci Niczyje przygotowany w ramach kampanii społecznej Mama, tata, tablet, https://www.youtube.com/watch?v=YmX20QCtBvw [dostęp: 6.01.2019].

Kocójowa M., Librarianship and Information Science Education and Library Staff Training in Poland, [w:] Modern Libraries and Librarianship in Poland, red. M. Kocójowa, A. Altenberger, Kraków 1995, s. 16-21.

Kocójowa M., Raport Katedry Bibliotekoznawstwa i Informacji Naukowej Uniwersytetu Jagiellońskiego w Krakowie, Kraków 1995, http://www.inib.uj.edu.pl/podstawowe-informacje [dostęp: 6.01.2019].

Międzywydziałowe Studium Bibliotekarstwa UJ, [w:] Spis wykładów na rok 1971/72 Wydziat Filozoficzno-Historyczny, Kraków 1971, z. 2, s. 72-74.

Nowak J., Biblioteka = przyjazne miejsce, „Biuletyn EBIB” 2016, nr 5, s. 1, http://open.ebib.pl/ojs/ index.php/ebib/article/view/448 [dostęp: 6.01.2019].

Plan studiów I stopnia na kierunku zarządzanie informacja - studia rozpoczynające się $w$ roku 17/18, http://www.inib.uj.edu.pl/studia-1-stopnia [dostęp: 6.01.2019]. 
Stachnik L., Zarys dziejów katalogu alfabetycznego Biblioteki Jagiellońskiej, „Biuletyn Biblioteki Jagiellońskiej" 25, 1975, s. 93-108.

Tokarska T., Biblioteka w przestrzeni informacyjnej, [w:] Bibliotekarstwo, red. A. Tokarska, Warszawa 2013, s. 93-108.

\title{
Źródła niepublikowane
}

Anna Grzęda, urodzona 16 września 1962 roku, wywiad przeprowadzony w Krakowie dnia 6 listopada 2017 roku.

„Ariadna w labiryncie informacji: 60-lecie Oddziału Informacji Naukowej i Katalogów Biblioteki Jagiellońskiej" (11 stycznia 2011), materiały robocze zebrane w celu opracowania wystawy.

Barbara Bułat, urodzona 18 lipca 1962 roku, wywiad przeprowadzony w Krakowie dnia 17 października 2017 roku.

Barbara Bułat, urodzona 18 lipca 1962 roku, wywiad przeprowadzony w Krakowie dnia 6 listopada 2017 roku

Indeks Barbary Bułat wystawiony przez Uniwersytet Jagielloński w dniu 1 października 1981 roku. Indeks Jagody Nowak wystawiony przez Uniwersytet Jagielloński w dniu 1 października 1981 roku. Okólnik nr 7 z 22 stycznia 1951 dotyczący przydziału maszyn do pisania.

Okólnik nr 27 z 28 lipca 1954 B-1a/27/3/54 dotyczący uruchomienia centrali telefonicznej.

Planowanie budżetowe na rok 1956 w Oddziale Informacji Bibliograficznej z dnia 30 czerwca 1955 roku.

Sprawozdania Oddziału Informacji Naukowej za lata 1991-2010.

\section{The work of the librarians of the Reference Department of the Jagiellonian Library over the years}

\begin{abstract}
Summary
Everyone can see what the library does, but is one aware of what tasks were involved and fall under the responsibility of a librarian? Based on the interviews conducted with librarians of the Reference Department of the Jagiellonian Library, the basic changes that have taken place in the librarian's profession will be discussed. Review of old and current librarian work tools, as well as the scope of its duties will be compared. The aim of the work is to show the process of evolution of the librarian's profession, with particular emphasis on changes that have occurred in the area of work tools and the manner of performed tasks.
\end{abstract}

KEYWORDS: information science, librarianship, library services, library equipment, databases, library workshops 